GRASAS Y ACEITES 68 (2)

April-June 2017, e190

ISSN-L: 0017-3495

doi: http://dx.doi.org/10.3989/gya.0939162

\title{
Characterization of Leucaena (Leucaena leucephala) oil by direct analysis in real time (DART) ion source and gas chromatography
}

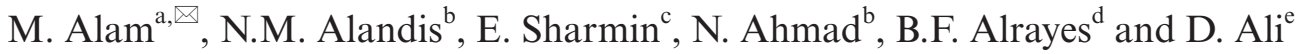 \\ ${ }^{a}$ Research Center-College of Science, King Saud University, P.O. Box 2455, Riyadh 11451, Saudi Arabia \\ ${ }^{b}$ Department of Chemistry, College of Science, King Saud University, P.O. Box 2455, Riyadh 11451, Saudi Arabia \\ DDepartment of Pharmaceutical Chemistry, College of Pharmacy, Umm Al-Qura University, P.O. Box 715, \\ Makkah Al-Mukarramah 21955, Saudi Arabia \\ ${ }^{d}$ Central Laboratory, College of Science, Riyadh-11451, King Saud University, Kingdom of Saudi Arabia \\ ${ }^{e}$ Department of Zoology, College of Science, Riyadh-11451, King Saud University, Kingdom of Saudi Arabia \\ ${ }^{\circledR}$ Corresponding author: malamiitd@gmail.com
}

Submitted: 12 September 2016; Accepted: 06 February 2017

SUMMARY: For the first time, we report the characterization of triacylglycerols and fatty acids in Leucaena (Leucaena leucephala) oil [LUCO], an unexplored nontraditional non-medicinal plant belonging to the family Fabaceae. LUCO was converted to fatty acid methyl esters (FAMEs). We analyzed the triacylglycerols (TAGs) of pure LUCO and their FAMEs by time-of-flight mass spectrometry (TOF-MS) followed by multivariate analysis for discrimination among the FAMEs. Our investigations for the analysis of LUCO samples represent noble features of glycerides. A new type of ion source, coupled with high-resolution TOF-MS was applied for the comprehensive analysis of triacylglycerols. The composition of fatty acid based LUCO oil was studied using Gas Chromatography (GC-FID). The major fatty acid components of LUCO oil are linoleic acid $(52.08 \%)$ oleic acid $(21.26 \%)$, palmitic acid $(7.91 \%)$ and stearic acid (6.01\%). A metal analysis in LUCO was done by Inductively Coupled Plasma Mass Spectrometry (ICP-MS). The structural elucidation and thermal stability of LUCO were studied by FT-IR, ${ }^{1} \mathrm{H}$ NMR, ${ }^{13} \mathrm{C}$ NMR spectroscopic techniques and TGA-DSC, respectively. We also measured the cytotoxicity of LUCO.

KEYWORDS: Cytotoxicity; Gas Chromatography; Leucaena oil; Thermal analysis; TOF-MS

RESUMEN: Caracterización del aceite de Leucaena (Leucaena leucocephala) por análisis directo en tiempo real (DART) y cromatografía de gases. Se presenta por primera vez la caracterización de triacilgliceroles y ácidos grasos del aceite de Leucaena (Leucaena leucephala) [LUCO], una planta no medicinal, no tradicional y no explorada, perteneciente a la familia Fabaceae. Se analizaron triacilgliceroles (TAGs) de LUCO y sus FAMEs por espectrometría de masas de tiempo de vuelo (TOF-MS) seguido de análisis multivariante para discriminación entre los FAME. Nuestras investigaciones para el análisis de muestras de LUCO presentaron características propias de los glicéridos. Un nuevo tipo de fuente de iones, junto con alta resolución TOF-MS se aplicó para el análisis exhaustivo de triacilgliceroles. La composición de aceite de LUCO basado en ácidos grasos se estudió usando Cromatografía de Gas (GC-FID). Los principales componentes de ácidos grasos del aceite LUCO fueron, linoleico $(52,08 \%)$, oleico $(21,26 \%)$, palmítico $(7,91 \%)$ y esteárico $6,01 \%$. El análisis de metales se realizó mediante Espectrometría de Plasma Acoplado Inductivamente a Masas (ICP-MS). La elucidación estructural y la estabilidad térmica de LUCO se estudiaron mediante FT-IR, ${ }^{1} \mathrm{H}$ NMR, técnicas espectroscópicas de ${ }^{13} \mathrm{C}$ NMR y TGA-DSC, respectivamente. También se midió la citotoxicidad de LUCO.

PALABRAS CLAVE: Aceite de Leucaena; Análisis Térmico; Citotoxicidad; Cromatografía de gases; TOF-MS

ORCID ID: Alam M http://orcid.org/0000-0001-9540-8532, Alandis NM http://orcid.org/0000-0002-2098-9800, Sharmin E http://orcid.org/0000-0002-3262-0162, Ahmad N http://orcid.org/0000-0002-2913-1763, Alrayes BF http:// orcid.org/0000-0002-5319-2785, Ali D http://orcid.org/0000-0002-8034-4473

Citation/Cómo citar este artículo: Alam M, Alandis NM, Sharmin E, Ahmad N, Alrayes BF, Ali D. 2017. Characterization of Leucaena (Leucaena leucephala) oil by direct analysis in real time (DART) ion source and gas chromatography. Grasas Aceites 68 (2), e190. http://dx.doi.org/10.3989/gya.0939162

Copyright: (C) 2017 CSIC. This is an open-access article distributed under the terms of the Creative Commons Attribution (CC-by) Spain 3.0 License. 


\section{INTRODUCTION}

The precise word 'leucocephala' derived from 'leu', meaning white, and 'cephala', meaning head, refers to flowers. Leucaena leucocephala is essentially a tropical species requiring warm temperatures $\left(15-25^{\circ} \mathrm{C}\right)$ for optimum growth (Mullen et al., 2003). It is found in regions of Australia, US, Philippines, Thailand, China, Pacific islands, Mexico and India. In India, it is commonly known as Subabul / Kababul. It belongs to the family Fabaceae (Leguminosae) and sub-family Mimosaceae. The legume size is $10-17 \mathrm{~cm}$ long containing 15-25 seeds each (Muthukrishnan et al., 2013). L. leucocephala is a fast growing hedgerow, medium-sized shrub. It is used in alley cropping and can release enough nitrogen to satisfy the requirement of maize grown in the alley crops (Mulongy et al., 1998). Its pod extract is a cheap, nontoxic and environmentally friendly natural product, used as corrosion inhibitor in an acidic medium (Muthukrishnan et al., 2013). The need for vegetable oils characterization arises in many aspects such as product development, quality assurance, product shelf life, and detection of adulteration. The industrial value of vegetable oils depends on their fatty acid composition and the ease by which these can be modified (Bhatnagar et al., 2009).

The most common method for the analysis of vegetable oils is gas chromatography. This technique is based on the selection of stationary phases, mobile phases, detectors, column temperature program and an appropriate resolution of carbon chain. Several scientific instruments are used to develop rapid, reliable and cost effective techniques for the analysis of vegetable oils such as gas chromatography-mass spectroscopy (GC-MS), high performance liquid chromatography (HPLC), matrix assisted laser desorption/ionization mass spectrometry (MALDI) and others (Dugo et al., 2012; Mercy et al., 2016; Kubo et al., 2013). TOF-MS techniques are advanced, efficient, much faster, have high data acquisition rate and a small internal volume for mass analysis (Vaclavik et al., 2009). Other advantages include rapid screening for target analytes, identification of non-target analytes by accurate-mass determination of protonated or de-protonated molecules and their product-ion mass spectra, quantification capability or performance, and reproducibility. The most frequently employed MS-related technique for the direct analysis of samples is direct analysis- inreal- time (DART) coupled with quadrupole timeof-flight mass spectrometry (Q-TOFMS).

In TOF analysis, molecules are charged by applying voltage between orifice and optics lens of ion source; the mass profile produced by applied voltage can be varied with respect to the amount of charged fragmentation. Typically, at low potential difference, positively charged species pass into the flight tube while at higher potential difference, induced-collision takes place which provides more spectral and isomeric information through fragmentation. TOF software has the ability to collect various orifice voltages consecutively, giving a full profile of a sample (Mess et al., 2013; GómezGonza et al., 2011).

The present study investigated the triacylglycerols (TAGs) of pure L. leucocephala oil [LUCO] and their FAMEs by TOF-MS, fatty acid composition by GC, structural analysis by FT IR, ${ }^{1} \mathrm{H}$ NMR,${ }^{13} \mathrm{C}$ NMR and thermal stability by TGA-DSC. We also measured the cytotoxicity of LUCO.

\section{MATERIALS AND METHODS}

\subsection{Materials}

We collected ripe legumes from the L. leucocephala plant (University Campus, King Saud University) and ginning seeds. Seeds were powdered, and the oil was extracted from powdered seeds through a soxhlet apparatus using petroleum ether as solvent. After extraction, petroleum ether was removed by a vacuum rotatory evaporator and yield was found as $5.67 \%$. Petroleum ether, sulphuric acid (BDH, Poole, England), and methanol (Sigma-Aldrich, Steinheim, Germany) were used without any further purification.

\subsection{Instrumentation and testing conditions}

For the experiments, an Accu TOF LC plus (JMS-T 100LP) system consisting of a DART ion source (IonSense, DART), an Accu TOF LC plus a higher solution time-of-flight mass spectrometer (JEOL, Japan) and an auto injection valve were used. The operating conditions of the DART ion source were as follows: positive ion mode; discharge needle voltage: $3.0 \mathrm{kV}$; perforated and grid electrode potentials: +100 and $-100 \mathrm{~V}$, respectively. Conditions of TOF-MS: cone voltage: $2000 \mathrm{~V}$, monitored mass range: $\mathrm{m} / \mathrm{z}$ 50-10000; acquisition rate: 1600 spectra min $^{-1}$; resolving power: approx. 6000 FWHM (full width at half maximum). The distance between the DART gun exit and mass spectrometer inlet was $7 \mathrm{~mm}$. The sampling glass rod was immersed for $1 \mathrm{~s}$ into the sample containing approx. $500 \mu \mathrm{L}$ of the respective sample and was transferred to the optimized position in front of the DART gun exit and desorbed for $5 \mathrm{~s}$, while the spectral data were recorded. For each sample/PEG standard, a minimum of three repeated measurements were carried out. At the end of each run, the mass spectra of polyethylene glycol (PEG, average relative molecular weight 600/1000, Sigma-Aldrich, USA) methanol solution $(200 \mu \mathrm{L} /$ $\mathrm{mL}^{-1}$ ) were acquired to perform mass drift compensation (Easter J L et al., 2014; Wang Wang Y et al., 2014). The influence of gas beam temperature on signal intensity, LUCO and FAMEs were analyzed at $200{ }^{\circ} \mathrm{C}$. The final spectra were obtained after the 
background was subtracted. The operating conditions were as follows: Gas Chromatography, Clarus 500 GC with FID, Perkin Elmer, USA, Column: Supelco Wax, $30 \mathrm{~m}$ long, $0.32 \mathrm{~mm}$ id, phase thickness $0.25 \mu \mathrm{m}$, injection mode: split; split ratio, 1:100, $1.0 \mu \mathrm{L}$ injection used, diluted $(1 / 10 \mathrm{v} / \mathrm{v}, \mathrm{FAMEs} / \mathrm{hex}-$ ane), Column temperature $140-240{ }^{\circ} \mathrm{C}, 4^{\circ} \mathrm{C} / \mathrm{min}$, an initial temperature hold at $140{ }^{\circ} \mathrm{C}$ for $5 \mathrm{~min}$, FID temperature $260{ }^{\circ} \mathrm{C}$, Helium carrier gas flow $1.0 \mathrm{~mL} /$ min, Hydrogen $30 \mathrm{~mL} / \mathrm{min}$, Air $300 \mathrm{~mL} / \mathrm{min}$. The FAMEs mix standard was analyzed under the same operating conditions to determine the peak identity. The FAMEs were expressed as relative area percentage (Dodds et al., 2005; Fardin-Kia et al., 2013).

LUCO spectra were taken on a FT IR spectrometer, Spectrum 100, Perkin Elmer, USA. ${ }^{1} \mathrm{H}$ and ${ }^{13} \mathrm{C}$ NMR spectra were recorded on Jeol DPX400 $\mathrm{MHz}$ using deuterated chloroform as solvent and tetra methyl silane as an internal standard. The thermal analysis of LUCO was carried out by simultaneous thermogravimetric analysis-differential scanning calorimetry (TGA-DSC) (Model TGA/DSC1, Mettler Toledo AG, Analytical CH-8603, Schwerzenbach, Switzerland) in nitrogen atmosphere (99.997 purity). The metal analysis of acid digested LUCO oil was analyzed with Inductively Coupled Plasma-Mass Spectroscopy (ICP-MS); ThermoScientific, Instrument, USA.

\subsubsection{Preparation of FAMEs of $L U C O$}

Initially LUCO was derivatized by the alkaline saponification of vegetable oil (to break down glycerides because of their low volatility in nature) and was further esterified in the presence of methanol and a catalyst. LUCO $(500 \mathrm{mg})$ was refluxed with a $5 \mathrm{~mL}$ methanolic sodium hydroxide $(0.5 \mathrm{M})$ solution at $150 \pm 5{ }^{\circ} \mathrm{C}$ for 5 minutes on a hot plate. $5 \mathrm{~mL}$ of a boron trifluoride methanol solution were added and the whole content was further heated at $150 \pm 5{ }^{\circ} \mathrm{C}$ for 5 minutes. The flask was removed from the hot plate; $5 \mathrm{~mL}$ of $\mathrm{n}$-hexane and $10 \mathrm{~mL}$ of a saturated aqueous sodium chloride solution were added and the contents were agitated thoroughly. An aliquot of supernatant hexane layer was transferred into anhydrous sodium sulphate to remove moisture. The above $10 \mu \mathrm{L}$ filtrate was analyzed by GC-FID (Lee et al., 1998; Reiter et al., 2001; Řezanka et al., 2001).

\subsection{Digestion of LUCO for ICP-MS}

A certain amount $(250 \mathrm{mg})$ of LUCO sample was put into a digestive vessel of $60 \mathrm{~mL}$ capacity, with $8 \mathrm{~mL}$ of $65 \%$ nitric acid and the mixture was shaken carefully with a clean polytetrafluroethylene (PTFE) bar. After 30 minutes, the vessel was closed. The sample and blank (without oil) vessels were placed in the Topwave Analytik Jena microwave for digestion and the program temperature was set at
$140{ }^{\circ} \mathrm{C}, 50$ bar pressure for 8 minutes (ramp). The vessels were then left to cool at room temperature. The digested aliquots were filtered with a whatman no. 42 filter paper and the filtrate was diluted with $50 \mathrm{~mL}$ deionized water (Pehlivana et al., 2008; Hsu W H et al., 2013). ICP-MS calibration was carried out by external calibration using $10 \mathrm{ppm}$ of multi element standard solutions (Aristar grade, $\mathrm{BDH}$ laboratory supplies, England) for the trace elements. The sample and blank were analyzed in triplicate. The results are summarized in Table 1.

\subsection{Cytotoxicity studies 3-(4,5-dimethylthiazol-2-yl)- 2,5-diphenyltetrazolium bromide (MTT) assay}

The MTT viability assay was performed with slight modifications as previously described (Mosmann T, 1983). Human hepatocarcinoma (HepG2) cells (2 $\times 10^{3}$ ) were seeded in 96 well plates and incubated in a $\mathrm{CO}_{2}$ incubator at $37{ }^{\circ} \mathrm{C}$ for 24 hour. The cells were exposed to the culture medium and LUCO $(0$, $50,100,300,700 \mu \mathrm{L} / \mathrm{mL}$ ) for $24 \mathrm{~h}$. After exposure, $100 \mu \mathrm{L}$ of a MTT solution was added to each well and incubated for 4 hour at $37^{\circ} \mathrm{C}$. After incubation the formed formazon crystal was dissolved in DMSO $(100 \mu \mathrm{L})$. Absorbance was taken at $530 \mathrm{~nm}$ using the enzyme-linked immune sorbent assay (ElISA) reader and the cell viability was calculated as:

Cell viability $(\%)=$ Total cells - Viable cells $\times 100$

Total cells

\section{RESULTS AND DISCUSSION}

\subsection{TOF-MS spectra of LUCO}

The representative TOF-MS spectra of LUCO are shown in Figure 1. The spectra were divided into three categories according to ion fragmentations. The elemental $(\mathrm{C}, \mathrm{H}, \mathrm{O})$ compositions of the major peaks were calculated by a software based on the exact mass number of the elements. The mass differences of identified compounds differed from their theoretical mass numbers by less

TABLE 1. List of trace metals present in LUCO

\begin{tabular}{lc}
\hline Metals & Concentration (ppb) \\
\hline $\mathrm{Mn}$ & 2.940 \\
$\mathrm{Fe}$ & 16.80 \\
$\mathrm{Co}$ & 0.414 \\
$\mathrm{Ni}$ & 12.81 \\
$\mathrm{Zn}$ & 28.50 \\
$\mathrm{Cd}$ & 0.013 \\
$\mathrm{Pd}$ & 0.603 \\
\hline
\end{tabular}


than $5.0 \mathrm{mmu}$ (Table 2). Our target focused only on triglycerides, diglycerides and monoglycerides, and no other molecules. We tentatively identified triacylglycerol ion peaks of palmitoyldilinolein (PLnLn, m/z 854.736), trilinolein (LnLnLn, m/z 874.780), linolyldilinolein (LLnLn, $\mathrm{m} / \mathrm{z}$ 875.767), dipalmitoylbehenene (PPB, m/z 892.783), trilinolein (LLL, $\mathrm{m} / \mathrm{z} 879.743$ ), linolinediolein (LOO, $\mathrm{m} / \mathrm{z} 883.773$ ), triolein (OOO, $\mathrm{m} / \mathrm{z} 886.767)$, stearinedilinolien (SLnLn, m/z 879.743), gadolyldilinolein (GLnLn, m/z 906.782), archadoyldilinolien (A LnLn, m/z 907.748), gadoyldiolein (GLL, m/z 910.758), archedoyldilinolein (ALL, $\mathrm{m} / \mathrm{z}$ 912.770), gadoyldiolein (GOO, m/z 913.778), behenendilinolein (BLnLn, m/z 936.806), behenendiolein (BOO, $\mathrm{m} / \mathrm{z}$ 936.806), lenolyldistearine (LSS, $\mathrm{m} / \mathrm{z}$ 884.749), linolene digadolein (LnGG, m/z 938.803), olyldigadolein (OGG, m/z 942.821), linolyldiarchidein (LAA, m/z 944.827), and olyldiarchidiene (OAA, $\mathrm{m} / \mathrm{z}$ 946.816). However, the differentiation of positional isomers of TAGs with two or three different fatty acids is not possible by TOF-MS, due to the absence of separation of the isobaric molecules prior to ionization. The relative intensities of molecular adducts, as well as molecular ions are present in TOF-MS spectra (Vaclavik et al., 2009; Hajslova et al., 2011; Bosque-Sendra et al., 2012; $\mathrm{Xu}$ et al., 2015).

In the TOF-MS spectra (Figure 1), the extensive fragmentation of TAG acquisition resulted in the occurrence of numerous types of ions under the experimental conditions. The most abundant were diacylglycerol fragment ions created by the loss of one fatty acid molecule from the glycerol backbone.

Ions at m/z 593 to 709 were identified as markers for diacylglycerols fragment ions: palmitolinolein (PL, $\mathrm{m} / \mathrm{z}$ 593.493), oleyllinolein $(\mathrm{OL}, \mathrm{m} / \mathrm{z}$ $620.530)$, diolein $(\mathrm{OO}, \mathrm{m} / \mathrm{z}$ 623.530), palmitoylgadolein (PG, m/z 624.551), linolylarchidin (LnA, m/z
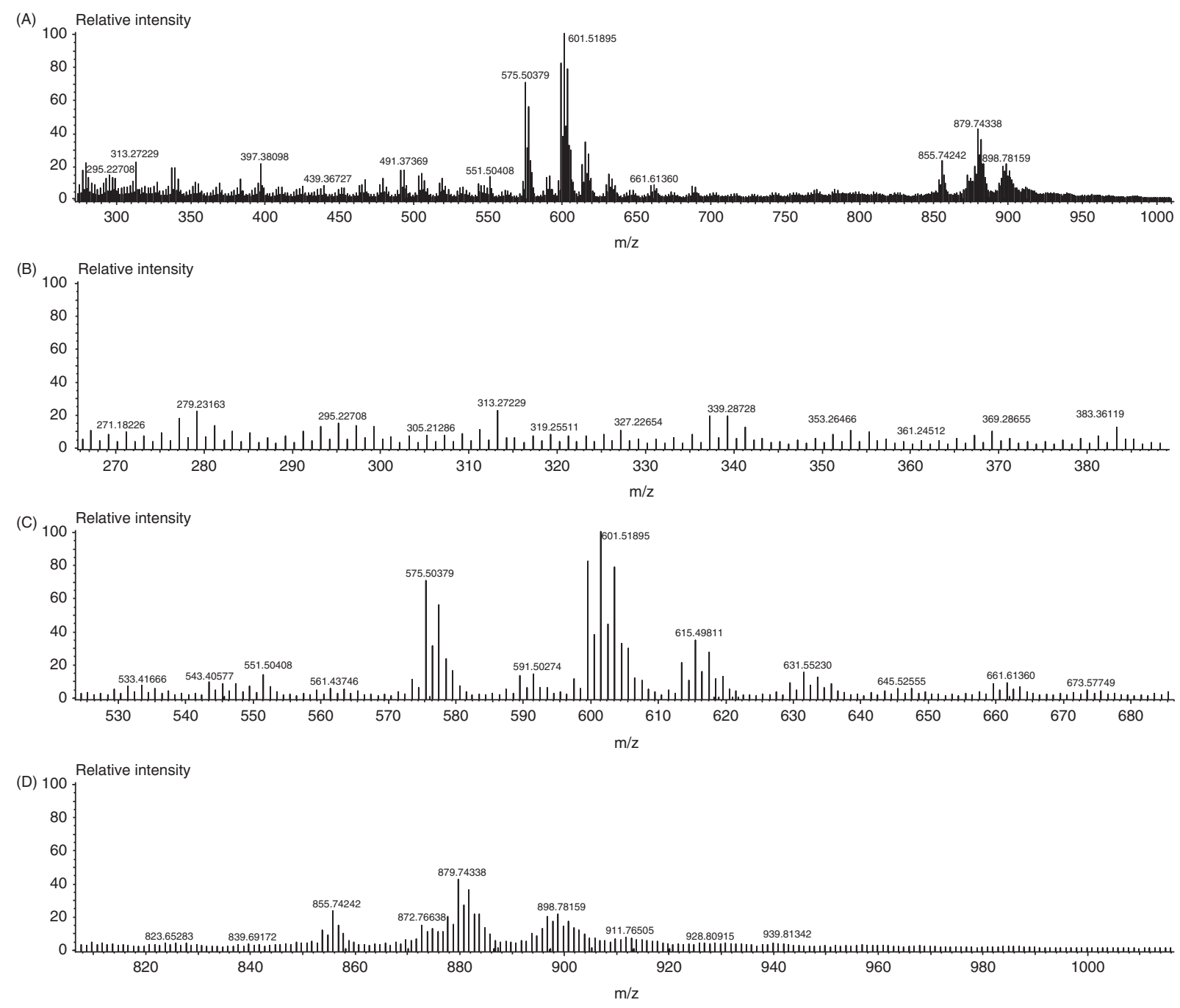

FIGURE 1. TOF- MS spectra of LUCO; (A) Full spectra; (B) monoglycerols; (C) diacylglycerol; (D) triacylglycerols. 
Characterization of Leucaena (Leucaena leucephala) oil by direct analysis in real time (DART) 5

TABLE 2. Mass spectral statistics MS-TOF analysis of LUCO

\begin{tabular}{|c|c|c|c|c|}
\hline S No. & Formula & Measured $(\mathrm{M}+\mathrm{H})^{+}$ & Difference (mmu) & Identification \\
\hline 1. & $\mathrm{C}_{19} \mathrm{H}_{38} \mathrm{O}_{4}$ & 330.2406 & 3.81 & $\mathrm{a}[\mathrm{P}]^{+}$ \\
\hline 2. & $\mathrm{C}_{20} \mathrm{H}_{38} \mathrm{O}_{4}$ & 341.2539 & -2.3 & $\mathrm{a}[\mathrm{L}]^{+}$ \\
\hline 3. & $\mathrm{C}_{20} \mathrm{H}_{41} \mathrm{O}_{4}$ & 345.5414 & -2.8 & $\mathrm{a}[\mathrm{S}]^{+}$ \\
\hline 4. & $\mathrm{C}_{21} \mathrm{H}_{36} \mathrm{O}_{4}$ & 352.2378 & 2.89 & $\mathrm{a}[\mathrm{Ln}]^{+}$ \\
\hline 5. & $\mathrm{C}_{21} \mathrm{H}_{40} \mathrm{O}_{4}$ & 357.2277 & -1.98 & $\mathrm{a}[\mathrm{O}]^{+}$ \\
\hline 6. & $\mathrm{C}_{22} \mathrm{H}_{45} \mathrm{O}_{4}$ & 373.601 & -3.10 & $\mathrm{a}[\mathrm{A}]^{+}$ \\
\hline 7. & $\mathrm{C}_{23} \mathrm{H}_{42} \mathrm{O}_{4}$ & 382.2437 & -1.28 & $\mathrm{a}[\mathrm{E}]^{+}$ \\
\hline 8. & $\mathrm{C}_{23} \mathrm{H}_{44} \mathrm{O}_{4}$ & 384.2857 & 2.74 & $\mathrm{a}[\mathrm{G}]^{+}$ \\
\hline 9. & $\mathrm{C}_{44} \mathrm{H}_{49} \mathrm{O}_{4}$ & 401.6514 & -2.64 & $\mathrm{a}[\mathrm{B}]^{+}$ \\
\hline 10. & $\mathrm{C}_{37} \mathrm{H}_{68} \mathrm{O}_{5}$ & 593.4934 & 0.81 & $\mathrm{~b}[\mathrm{PL}]^{+}$ \\
\hline 11. & $\mathrm{C}_{37} \mathrm{H}_{72} \mathrm{O}_{5}$ & 597.4925 & 0.90 & $\mathrm{~b}[\mathrm{PS}]^{+}$ \\
\hline 12. & $\mathrm{C}_{39} \mathrm{H}_{72} \mathrm{O}_{5}$ & 620.5301 & 0.47 & $\mathrm{~b}[\mathrm{OL}, \mathrm{LS},]^{+}$ \\
\hline 13. & $\mathrm{C}_{39} \mathrm{H}_{74} \mathrm{O}_{5}$ & 623.5327 & 3.90 & $\mathrm{~b}[\mathrm{OO}, \mathrm{OS}]^{+}$ \\
\hline 14. & $\mathrm{C}_{39} \mathrm{H}_{76} \mathrm{O}_{5}$ & 624.5512 & -0.38 & $\mathrm{~b}[\mathrm{PG}]^{+}$ \\
\hline 15. & $\mathrm{C}_{41} \mathrm{H}_{74} \mathrm{O}_{5}$ & 647.5403 & -0.74 & $\mathrm{~b}[\operatorname{Ln} \mathrm{A}, \mathrm{LnG}]^{+}$ \\
\hline 16. & $\mathrm{C}_{41} \mathrm{H}_{76} \mathrm{O}_{5}$ & 649.5978 & -0.37 & $\mathrm{~b}[, \mathrm{LG}]^{+}$ \\
\hline 17. & $\mathrm{C}_{41} \mathrm{H}_{78} \mathrm{O}_{5}$ & 651.5591 & -1.54 & $\mathrm{~b}[\mathrm{OG}, \mathrm{LA}, \mathrm{OA}, \mathrm{GS}]^{+}$ \\
\hline 18. & $\mathrm{C}_{41} \mathrm{H}_{80} \mathrm{O}_{5}$ & 653.0447 & -2.83 & $\mathrm{~b}[\mathrm{AS}]^{+}$ \\
\hline 19. & $\mathrm{C}_{43} \mathrm{H}_{80} \mathrm{O}_{5}$ & 677.6691 & -2.08 & $\mathrm{~b}[\mathrm{LnB}]^{+}$ \\
\hline 20. & $\mathrm{C}_{43} \mathrm{H}_{82} \mathrm{O}_{5}$ & 680.5545 & 0.04 & $\mathrm{~b}[\mathrm{LB}]^{+}$ \\
\hline 21. & $\mathrm{C}_{45} \mathrm{H}_{88} \mathrm{O}_{5}$ & 709.6644 & -4.37 & $\mathrm{~b}[\mathrm{AB}, \mathrm{GB}]^{+}$ \\
\hline 22. & $\mathrm{C}_{55} \mathrm{H}_{96} \mathrm{O}_{6}$ & 854.7364 & 0.05 & $\mathrm{c}[\mathrm{PLnLn}]^{+}$ \\
\hline 23. & $\mathrm{C}_{55} \mathrm{H}_{102} \mathrm{O}_{6}$ & 862.6908 & 0.89 & $\mathrm{c}[\mathrm{PSS}]^{+}$ \\
\hline 24. & $\mathrm{C}_{57} \mathrm{H}_{92} \mathrm{O}_{6}$ & 874.7808 & -2.87 & $c[\operatorname{LnLnLn}]^{+}$ \\
\hline 25. & $\mathrm{C}_{57} \mathrm{H}_{94} \mathrm{O}_{6}$ & 875.7674 & 2.84 & $\mathrm{c}[\operatorname{LLnLn}]^{+}$ \\
\hline 26. & $\mathrm{C}_{57} \mathrm{H}_{98} \mathrm{O}_{6}$ & 879.7434 & -0.79 & 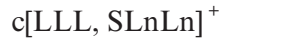 \\
\hline 27. & $\mathrm{C}_{57} \mathrm{H}_{100} \mathrm{O}_{6}$ & 881.7084 & -2.70 & {$[\mathrm{SOO}]^{+}$} \\
\hline 28. & $\mathrm{C}_{57} \mathrm{H}_{102} \mathrm{O}_{6}$ & 883.7738 & -1.7 & $\mathrm{c}[\mathrm{LOO}]^{+}$ \\
\hline 29. & $\mathrm{C}_{53} \mathrm{H}_{102} \mathrm{O}_{6}$ & 884.7497 & -3.77 & $\mathrm{c}[\mathrm{LSS}]^{+}$ \\
\hline 30. & $\mathrm{C}_{57} \mathrm{H}_{104} \mathrm{O}_{6}$ & 886.7672 & 4.69 & $\mathrm{c}[\mathrm{OOO}, \mathrm{SSS}, \mathrm{OSS}]^{+}$ \\
\hline 31. & $\mathrm{C}_{57} \mathrm{H}_{110} \mathrm{O}_{6}$ & 892.7832 & 0.94 & $\mathrm{c}[\mathrm{PBP}]^{+}$ \\
\hline 32. & $\mathrm{C}_{59} \mathrm{H}_{100} \mathrm{O}_{6}$ & 906.7822 & -0.75 & $\mathrm{c}[\mathrm{GLnLn}]^{+}$ \\
\hline 34. & $\mathrm{C}_{59} \mathrm{H}_{102} \mathrm{O}_{6}$ & 907.7449 & 3.41 & $\mathrm{c}[\mathrm{ALnLn}, \mathrm{ELL}]^{+}$ \\
\hline 35. & $\mathrm{C}_{59} \mathrm{H}_{104} \mathrm{O}_{6}$ & 910.7580 & 1.35 & $\mathrm{c}[\mathrm{GLL}]^{+}$ \\
\hline 36. & $\mathrm{C}_{59} \mathrm{H}_{106} \mathrm{O}_{6}$ & 912.7708 & -1.56 & $\mathrm{c}[\mathrm{ALL}]^{+}$ \\
\hline 37. & $\mathrm{C}_{59} \mathrm{H}_{108} \mathrm{O}_{6}$ & 913.7784 & -1.75 & $\mathrm{c}[\mathrm{GOO}]^{+}$ \\
\hline 38. & $\mathrm{C}_{59} \mathrm{H}_{108} \mathrm{O}_{6}$ & 914.7453 & 0.17 & $\mathrm{c}[\mathrm{GSS}]^{+}$ \\
\hline 39. & $\mathrm{C}_{59} \mathrm{H}_{110} \mathrm{O}_{6}$ & 916.7543 & -0.62 & $\mathrm{c}[\mathrm{ASS}]$ \\
\hline 40. & $\mathrm{C}_{59} \mathrm{H}_{114} \mathrm{O}_{6}$ & 920.7368 & 2.23 & $\mathrm{c}[\mathrm{PBB}]^{+}$ \\
\hline 41. & $\mathrm{C}_{61} \mathrm{H}_{106} \mathrm{O}_{6}$ & 936.8060 & -2.41 & $\mathrm{c}[\mathrm{BLnLn}]^{+}$ \\
\hline 42. & $\mathrm{C}_{61} \mathrm{H}_{108} \mathrm{O}_{6}$ & 938.8034 & 3.67 & $\mathrm{c}[\mathrm{GLnG}]^{+}$ \\
\hline 43. & $\mathrm{C}_{61} \mathrm{H}_{112} \mathrm{O}_{6}$ & 942.8215 & 2.21 & $\mathrm{c}[\mathrm{LnAA}, \mathrm{SGG}, \mathrm{OGG}]^{+}$ \\
\hline 44. & $\mathrm{C}_{61} \mathrm{H}_{114} \mathrm{O}_{6}$ & 944.8279 & 2.30 & $\mathrm{c}[\mathrm{LAA}, \mathrm{BSS}]^{+}$ \\
\hline 45. & $\mathrm{C}_{61} \mathrm{H}_{116} \mathrm{O}_{6}$ & 946.8167 & 2.53 & $\mathrm{c}[\mathrm{OAA}, \mathrm{BOO}]^{+}$ \\
\hline 46. & $\mathrm{C}_{63} \mathrm{H}_{116} \mathrm{O}_{6}$ & 970.8408 & -0.44 & $\mathrm{c}[\mathrm{GGG}]^{+}$ \\
\hline 47. & $\mathrm{C}_{63} \mathrm{H}_{118} \mathrm{O}_{6}$ & 972.8525 & 1.53 & $\mathrm{c}[\mathrm{EAA}, \mathrm{AGG}]$ \\
\hline
\end{tabular}


TABLE 2. (Continued) Mass spectral statistics MS-TOF analysis of LUCO

\begin{tabular}{|c|c|c|c|c|}
\hline S No. & Formula & Measured $(\mathrm{M}+\mathrm{H})+$ & Difference(mmu) & Identification \\
\hline 48. & $\mathrm{C}_{63} \mathrm{H}_{120} \mathrm{O}_{6}$ & 974.8371 & 0.98 & $\mathrm{c}[\mathrm{GAA}]^{+}$ \\
\hline 49. & $\mathrm{C}_{63} \mathrm{H}_{122} \mathrm{O}_{6}$ & 976.8440 & -1.9 & $\mathrm{c}[\mathrm{AAA}]^{+}$ \\
\hline 50. & $\mathrm{C}_{64} \mathrm{H}_{120} \mathrm{O}_{6}$ & 998.9008 & 1.03 & $\mathrm{c}[\mathrm{LnBB}]^{+}$ \\
\hline 51. & $\mathrm{C}_{65} \mathrm{H}_{122} \mathrm{O}_{6}$ & 1000.9268 & -0.94 & $\mathrm{c}[\mathrm{BGG}, \mathrm{LBB}]^{++}$ \\
\hline 52. & $\mathrm{C}_{65} \mathrm{H}_{124} \mathrm{O}_{6}$ & 1002.9171 & 1.35 & $\mathrm{c}[\mathrm{OBB}]^{+}$ \\
\hline 53. & $\mathrm{C}_{65} \mathrm{H}_{126} \mathrm{O}_{6}$ & 1005.8879 & 1.57 & $\mathrm{c}[\mathrm{BAA}]^{+}$ \\
\hline
\end{tabular}

Abbreviations:

Fragment ions of LUCO are indicated by the following legend: $\mathrm{P}=$ Palmitic; $\mathrm{Ln}=$ Linolenic; $\mathrm{L}=$ Lenoleic; $\mathrm{O}=\mathrm{Oleic}$; $\mathrm{G}=\mathrm{Gondoic}$; $\mathrm{B}=$ Behenic; Stearic

a-monoglycerols fragment ion

b-diglycerols fragment ion

c-triglycerols fragment ion

TABle 3. Fatty acid Composition of LUCO

\begin{tabular}{lllcr}
\hline S.No. & Fatty acid & Common Name & Abbreviation & \multicolumn{1}{c}{$\%$} \\
\hline 1. & Hexadecanoic acid & Palmitic acid & C16:0 & 13.91 \\
2 & Octadecanoic acid & Stearic acid & C18:0 & 6.01 \\
3. & Octadecenoic acid & Oleic acid & $\mathrm{C} 18: 1$ & 21.26 \\
4. & Octadecadieneoic acid & Linoleic acid & $\mathrm{C} 18: 2$ & 52.08 \\
5. & Octadecatrienoic acid & Linolenic acid(Ln) & $\mathrm{C} 18: 3$ & 1.21 \\
6 & Eicosanoic acid & Arachidic acid & $\mathrm{C} 20: 0$ & 1.78 \\
7. & Eicosenoic acid & Gondoic acid & $\mathrm{C} 20: 1$ & 0.98 \\
8. & Docosanoic acid & Behenic acid & $\mathrm{C} 22: 0$ & 1.75 \\
\hline
\end{tabular}

647.540), oleinecosadien (OS, m/z 623.532), oleylgadolein (OG, $\mathrm{m} / \mathrm{z}$ 651.559), Linolylbehenine ( $\mathrm{LnB}$, $\mathrm{m} / \mathrm{z}$ 677.669), Linolylbehenene (LB, m/z 680.5545), archideinstearine (AS, $\mathrm{m} / \mathrm{z}$ 653.0447), gadolein stearine (GS, $\mathrm{m} / \mathrm{z}$ 651.559), and archadeinbehenein $(\mathrm{AH}, \mathrm{m} / \mathrm{z}$ 709.6644). The main fragment ion $(\mathrm{m} / \mathrm{z}$ 601.51) was the base peak in all spectra of LUCO; the least intensive was the monoglycerol ion of its corresponding fatty acid ion (Wang et al., 2014). It is, therefore, TOF-MS followed by an appropriate method for the differentiation of TAGs for the identification of compounds.

These observations confirmed that the results obtained from TOF-MS data were good and it was the choice of instrument for the screening of vegetable oil. Therefore, it is necessary to resort to multivariate techniques, which are important and proven techniques for complex data analysis (Vaclavik et al., 2009). The fatty acids involved may all be the same or different number of acids in many possible combinations. It is precisely this variation which gives rise to the wide spectrum of vegetable oils. It is not possible here to write the exact fatty acid sequence of the triglycerides. TOF-MS provides us a new way for vegetable oil analysis with speed of analysis, simplicity of sample introduction, and high sensitivity (Lesiak A $\mathrm{D}$ et al., 2014). The TOF-MS technique has been applied for the first time for the profiling of LUCO and was done successfully.

\subsection{Fatty acid composition of LUCO}

The result of compositional determination based on peak area of LUCO is given in Table 3. Vegetable oils have a characteristic fatty acid composition that is useful for product authentication (TavassoliKafrani et al., 2016). On the other hand, fatty acid composition not only depends on species but on region, climate, degree of ripeness, harvesting and processing conditions. LUCO is rich in Linoleic acid $(52.08 \%)$; the fraction analyzed contains palmitic, stearic, oleic, linolenic, arachidic, gadoleic, and behenic acid (Nehdi et al., 2013, 2014).

\subsection{Spectral Analysis}

FTIR $\left(\mathrm{cm}^{-1}\right): \quad 3472.20, \quad 3008.54 \quad(-\mathrm{CCH}=\mathrm{CH}-\mathrm{C})$; $2926.07\left(\mathrm{CH}_{2}\right.$.symmetrical); 2854.82, asymmetrical); $1746.51 \quad(\mathrm{C}=\mathrm{O}$,ester $) ; 1661.00(-\mathrm{HC}=\mathrm{CH}-)$; 1465.33 (vibration of deformation- $\mathrm{CH}-$ ), 1377.63 (deformation vibration of methylene group), 1238.14 (deformation vibration in the plane of $=\mathrm{CH}$ from the unconjugated cis double bonds), 1163.72 (-CCOO-C); 1099.93,722.79 (vibration of C-C) (Figure 2) (Barison et al., 2010). 
${ }^{1} \mathbf{H}$ NMR, $\mathbf{C D C l}_{3}, \boldsymbol{\delta}$, ppm: $0.869-0.878\left(-\mathrm{CH}_{3}\right), 1.241-$ $1.291\left(-\mathrm{CH}_{2}-\right), 1.597\left(-\mathrm{O}-\mathrm{CO}-\mathrm{CH}_{2}-\mathrm{CH}_{2}-\mathrm{CH}_{2}\right), 2.011-$ $2.046\left(-\mathrm{CH}_{2}-\mathrm{CH}=\mathrm{CH}\right)-, 2.280-2.299 \quad(-\mathrm{OCO}-\mathrm{CH} 2-)$, $2.742-2.774 \quad\left(=\mathrm{CH}-\mathrm{CCH} \mathrm{H}_{2}-\mathrm{CCH}=\right), \quad 4.141-4.156$ $\left(\mathrm{CCH}_{2}-\mathrm{COCO}-\mathrm{CH}_{2}-\mathrm{C}\right), \quad 4.264-4.273$ (>CHOCO$\left.\mathrm{CH}_{2}-\mathrm{C}-\right)$, 5.330-5.362 (-CCH=CH-C-) (Figure 3).

${ }^{13} \mathbf{C}$ NMR, $\mathbf{C D C l}_{3}$, $\boldsymbol{\delta}$, ppm: 14.158-14.204 $\left(-\mathrm{CH}_{3}\right)$, $25.704,27.279,29.206-29.787,31.607\left(-\mathrm{CH}_{2}^{-}\right)$,

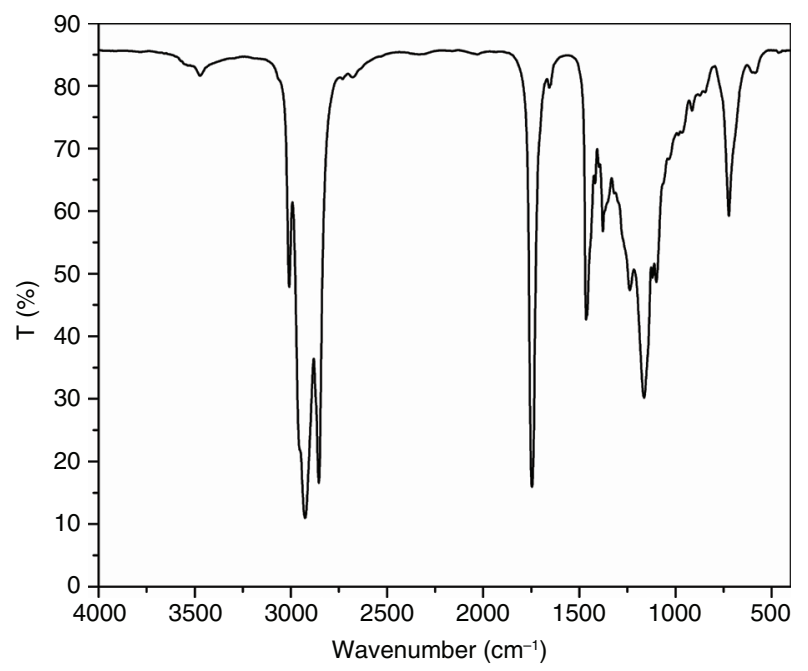

FIGURE 2. FTIR spectra of LUCO.
$62.177\left(>\mathrm{CHOCO}-\mathrm{CH}_{2}-\right), 68.944\left(-\mathrm{OCH}_{2}-\mathrm{CH}<\right)$, $127.966-130.298 \quad(-\mathbf{C H}=\mathbf{C H}-), \quad 172.911-173.332$ $(\mathbf{C}=\mathrm{O})$ (Figure 4) (Alam et al., 2014).

FTIR shows $-\mathrm{CH}_{2},-\mathrm{CH}_{3}$ symmetrical and asymmetrical absorption bands at $2926.07 \mathrm{~cm}^{-1}$ and at $2854.82 \mathrm{~cm}^{-1}$. The absorption bands for $-\mathbf{C H}=$ CH- str appear at $3008.54 \mathrm{~cm}^{-1}$ and also the carbonyl ester band at $1746.51 \mathrm{~cm}^{-1}$. The presence of unsaturation is also supported by characteristic peaks in the ${ }^{1} \mathrm{H}$ NMR and ${ }^{13} \mathrm{C}$ NMR spectra at $5.330-5.362 \mathrm{ppm}$ and $127.966-130.298 \mathrm{ppm}$, respectively. The rest of the characteristic peaks for typical functional groups in the LUCO backbone have been mentioned above.

\subsection{Thermal stability}

DSC (Figure 5) thermogram of L. leucocephala oil shows two endotherms, first at -30.25 to $-13.53{ }^{\circ} \mathrm{C}$, centered at $-24.51{ }^{\circ} \mathrm{C}$, the second endotherm starting at -11.50 to $8.57{ }^{\circ} \mathrm{C}$, centered at $3.33{ }^{\circ} \mathrm{C}$. The first endotherm belongs to phase transition and the second to melting. The TGADTG (Figure 6) thermogram shows the onset of degradation at $350{ }^{\circ} \mathrm{C}$, no weight loss was observed at this temperature; only 4\% weight loss occurs at $380{ }^{\circ} \mathrm{C}$ due to moisture and volatile impurities. $50 \%$ weight loss occurs at $460{ }^{\circ} \mathrm{C}$. The TGA thermogram shows single step degradation.

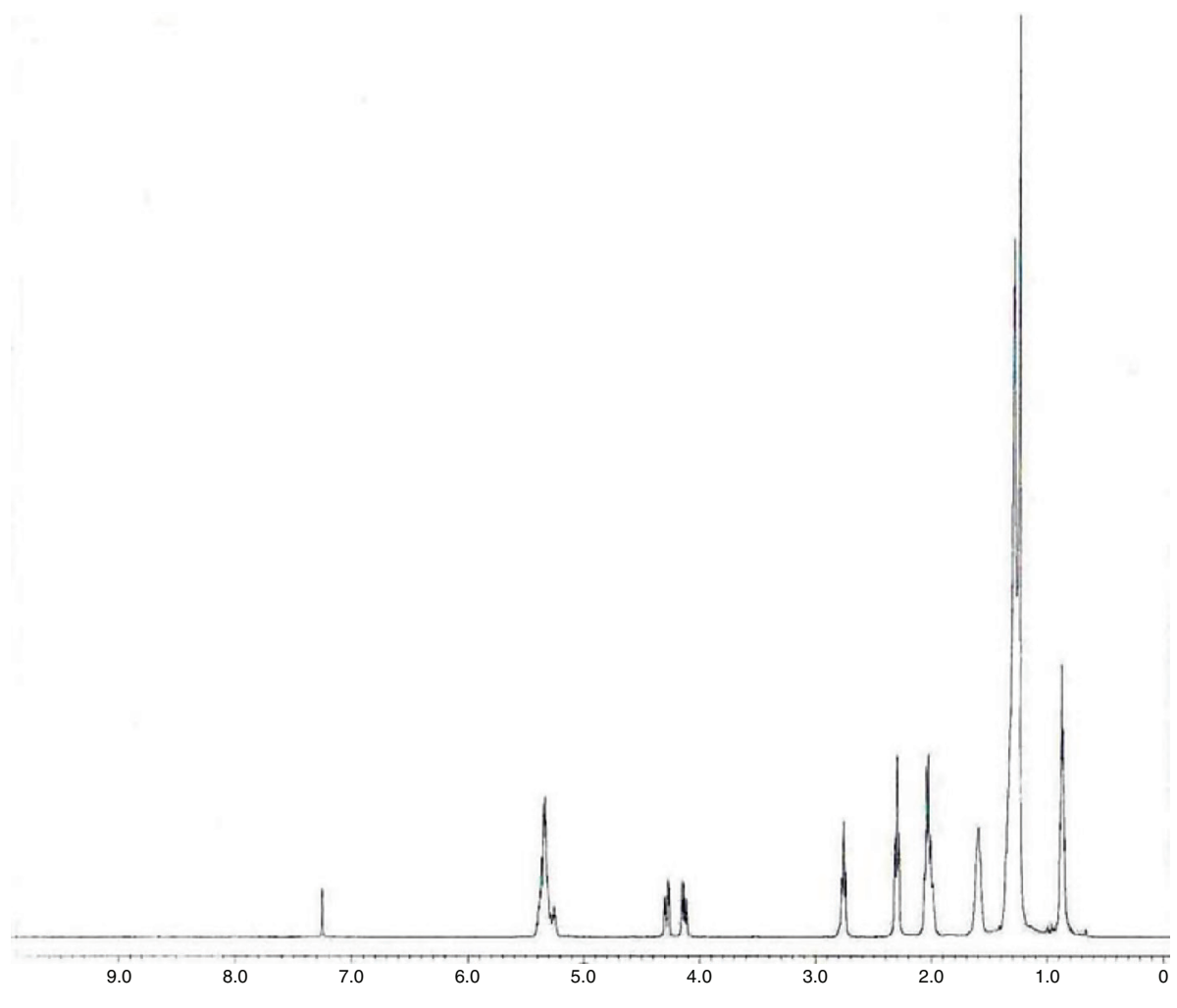

FigURE 3. $\quad{ }^{1}$ H NMR Spectra of LUCO. 


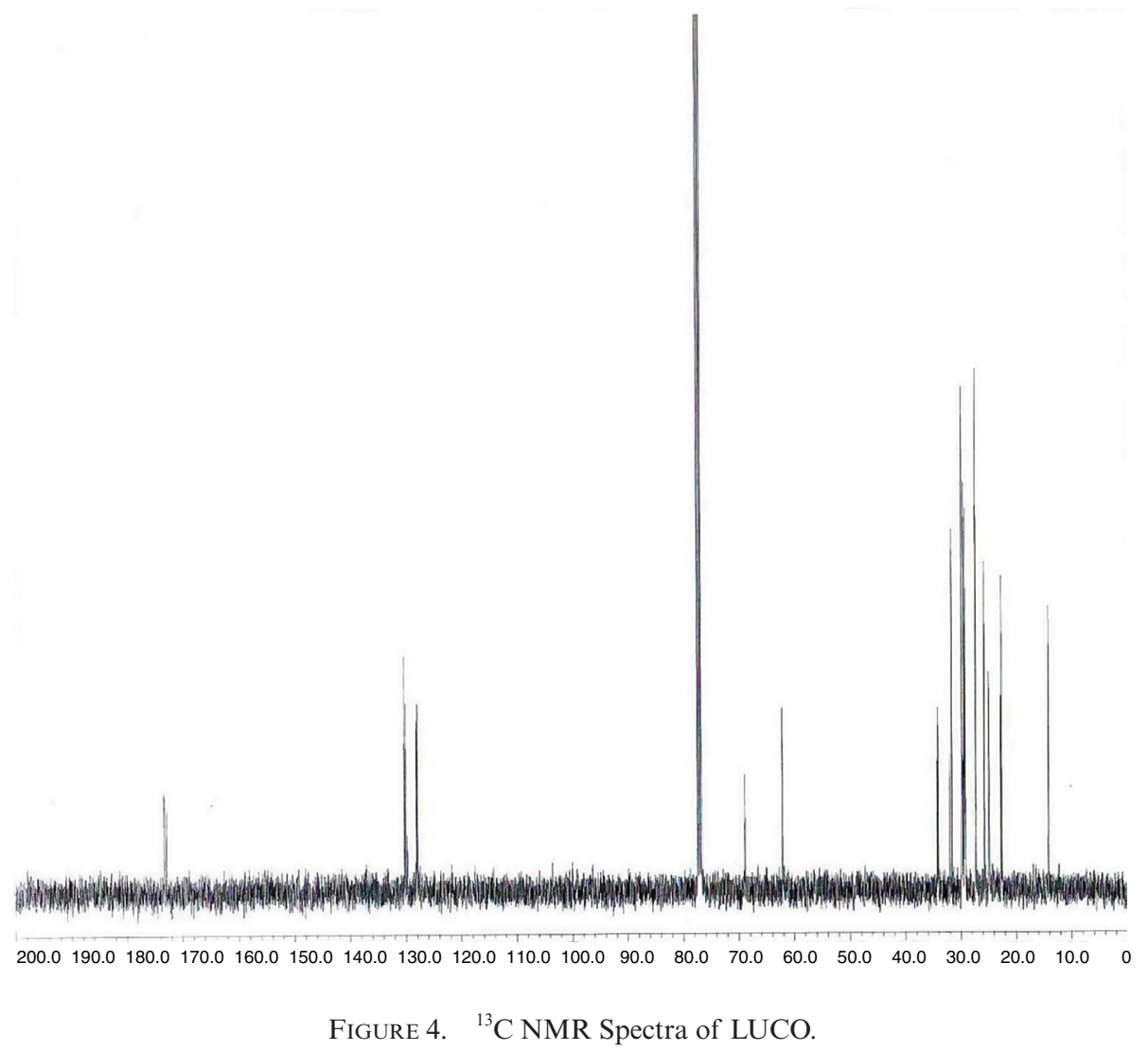

At $525^{\circ} \mathrm{C}$, a complete decomposition of oil occurs. This decomposition is assigned to the degradation of the hydrocarbon chain of the oil. In the DTG curve, an endothermic transition between $375^{\circ} \mathrm{C}$ and $525^{\circ} \mathrm{C}$ assigned to the hydrocarbons was also observed. The maximum weight loss of the sample according to the DTG curve was observed at $375^{\circ} \mathrm{C}$ to $525^{\circ} \mathrm{C}$.

\subsection{HepG2 cells toxicity}

Figure 7 shows the growth inhibition graph of LUCO at different doses $(0,50,100,300,700 \mu \mathrm{L} / \mathrm{mL})$. Taking the results of all concentrations into account, the cell death in HepG2 cells was found to be higher at ( $700 \mu \mathrm{L} / \mathrm{mL}$ ) by the MTT assay. This result shows that the cytotoxicity of HepG2 cells was oil dose dependent. In this study, we quantified the cytotoxicity of oil in human hepatocarcinoma cells for 24 hour by employing the MTT test. Finally, $\mathrm{IC}_{50}$ values were calculated for the oil according to the MTT test.

\section{CONCLUSION}

The TOF-MS technique was effectively applied to study the composition of the TAGs of LUCO. The applied operating conditions of the DART ion source were successfully investigated to obtain the best detection limit with high quality mass profile. The TOF-MS finger prints study could provide a useful technique for the rapid identification of vegetable oil, finding of adulteration, quality assurance, and the evaluation of similarities and improvement

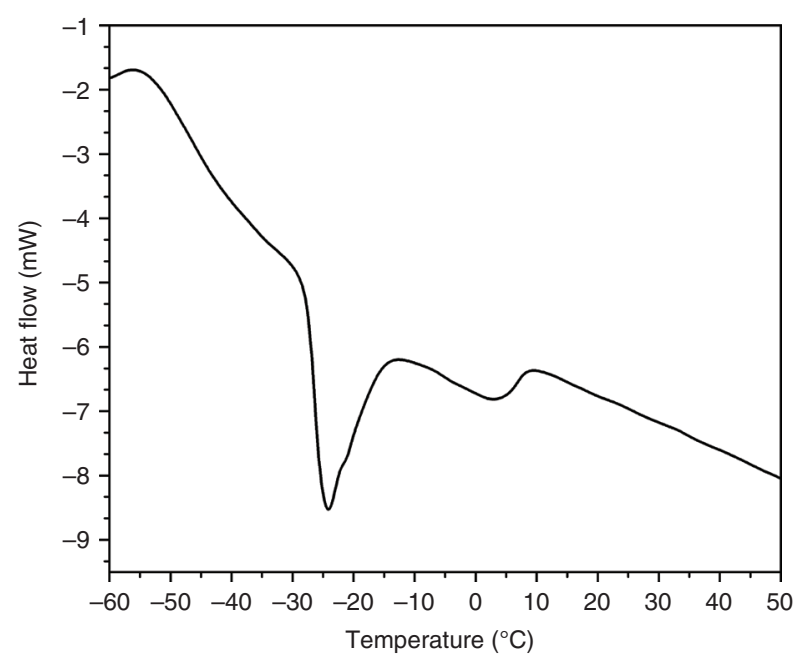

FIGURE 5. DSC thermogram of LUCO. 


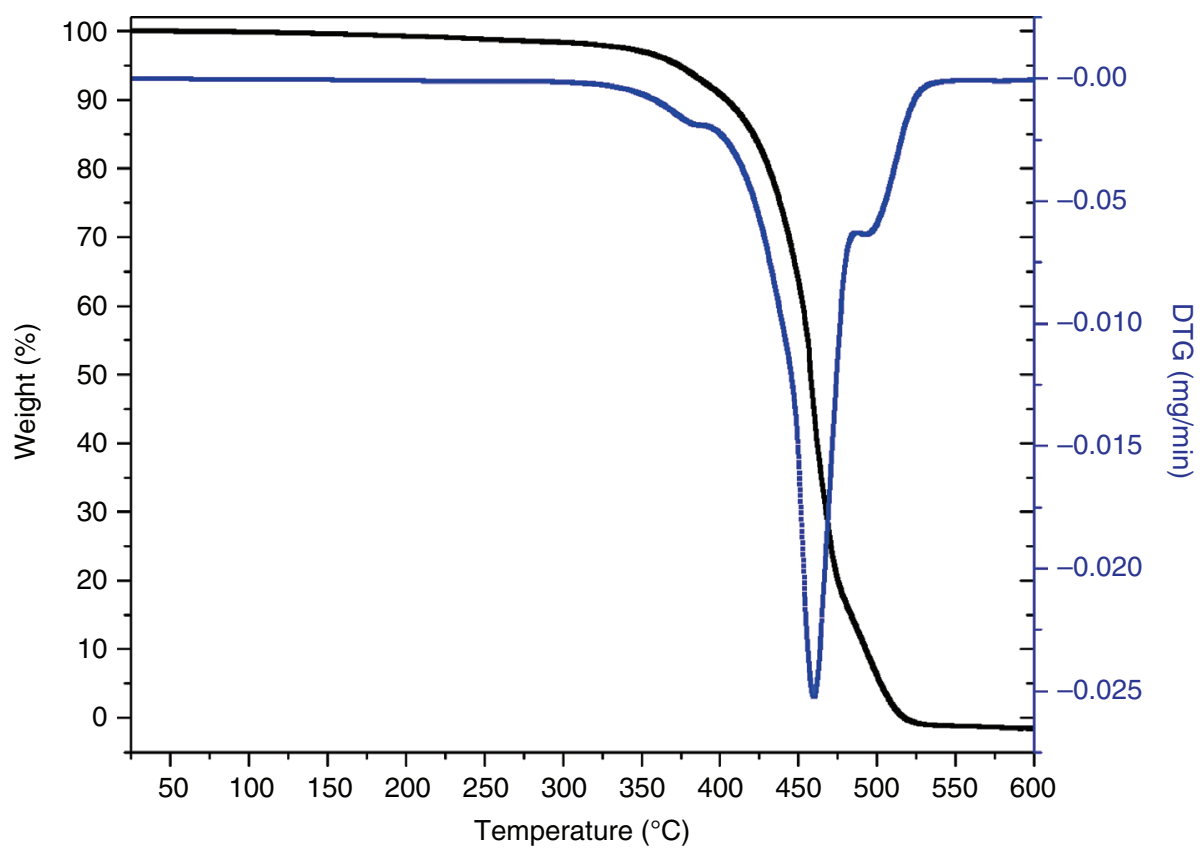

FIGURE 6. TGA-DTG thermogram of LUCO.

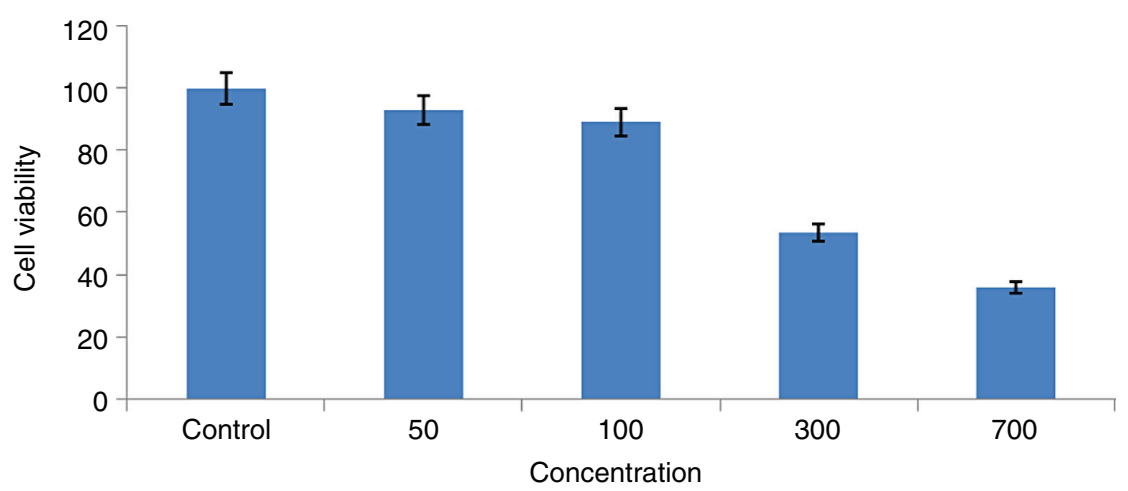

FIgURE 7. Cytotoxicity of HepG2 cells due to different concentrations of LUCO.

of product quality. The fatty acid profile plays a key role to the physico-chemical properties for further advanced research.

\section{ACKNOWLEDGEMENTS}

The Project was supported by King Saud University, Deanship of Scientific Research, College of Science - Research Center.

\section{REFERENCES}

Alam M, Alandis NM. 2014. Corn oil based poly(ether amide urethane) coating material-Synthesis, characterization and coating properties. Ind. Crops Prod. 57, 17-28. http:// dx.doi.org/10.1016/j.indcrop.2014.03.023

Barison A, Silva CWP, Campos FR, Simonelli F, Lenz CA, Ferreira AG. 2010. A simple methodology for the determination of fatty acid composition in edible oils through
${ }^{1}$ H NMR spectroscopy. Magn. Reson. Chem. 48, 642-650. http://dx.doi.org/10.1002/mrc.2629

Bhatnagar AS, Kumar PKP, Hemavathy J, Krishna AGG.2009. Fatty acid composition, oxidative stability, and radical scavenging activity of vegetable oil blends with coconut oil. J. Am. Oil Chem. Soc. 86, 991-999. http://dx.doi. org/10.1007/s11746-009-1435-y

Bosque-Sendra JM, Cuadros-Rodrígueza L, Ruiz-Samblása C, de la Mata AP, 2012. Combining chromatography and chemometrics for the characterization andauthentication of fats and oils from triacylglycerol compositional data-A review. Anal. Chim. Acta 724, 1-11. http://dx.doi. org/10.1016/j.aca.2012.02.041

Dodds ED, Mc Coya MR, Rea LD, Kennish JM, 2005. Gas chromatographic quantification of fatty acid methyl esters: flame ionization detection vs. electron impact mass spectrometry. Lipids 40, 419-428. https://doi.org/10.1007/ s11745-006-1399-8

Dugo G, Bonaccorsi I, Sciarrone D, Schipilliti L, Russo M, Cotroneo A, Dugo P, Mondello L, Raymo V. 2012. Characterization of cold-pressed and processed bergamot oils by using GC-FID, GC-MS, GC-C-IRMS, enantio-GC, 
MDGC, HPLC and HPLC-MS-IT-TOF. J. Essent. Oil Res. 24.93-117. http://dx.doi.org/10.1080/10412905.2012.659526

Easter JL, Steiner RR. 2014. Pharmaceutical identifier confirmation via DART-TOF. Forensic Sci. Int. 240,9-20. http:// dx.doi.org/10.1016/j.forsciint.2014.03.009

Fardin-Kia AR, Delmonte P, Kramer JKG, Jahreis G, Kuhnt K, Santercole V, Rader JI. 2013. Separation of the fatty acids in menhaden oil as methyl esters with a highly polar ionic liquid gas chromatographic column and identification by time of flight mass spectrometry. Lipids 48, 1279-1295. http://dx.doi.org/10.1007/s11745-013-3830-2

Gómez-González S, Ruiz-Jiménez J, Luque de Castro MD. 2011. Oil content and fatty acid profile of Spanish cultivars during olive fruit ripening. J. Am Oil Chem. Soc. 88, 1737-1745. http://dx.doi.org/10.1007/s11746-011-1840-x

Hajslova J, Cajka T, Vaclavik L. 2011. Challenging applications offered by direct analysis in real time (DART) in foodquality and safety analysis. Trends Anal. Chem. 30, 204 218. http://dx.doi.org/10.1016/j.trac.2010.11.001

Hsu WH, Jiang SJ, Sahayam AC. 2013. Determination of $\mathrm{Cu}$, $\mathrm{As}, \mathrm{Hg}$ and $\mathrm{Pb}$ in vegetable oils by electrothermal vaporization inductively coupled plasma mass spectrometry with palladium nanoparticles as modifier. Talanta 117, 268-272. http://dx.doi.org/10.1016/j.talanta.2013.09.013

Kubo A, Satoh T, Itoh Y, Hashimoto M, Tamura J, Cody RB. 2013. Structural analysis of triacylglycerols by using a MALDITOF/TOF System with monoisotopic precursor selection. J. Am. Soc. Mass Spectrom. 24, 684-689. http:// dx.doi.org/10.1007/s13361-012-0513-9

Lesiak A D, Cody R B, Dane A J, Musah R A. 2014. Rapid detection by direct analysis in real time-mass spectrometry(DART-MS) of psychoactive plant drugs of abuse: The case of mitragyna speciosa aka "Kratom". Forensic. Sci. Int. 242, 210-218. http://dx.doi.org/10.1016/j. forsciint.2014.07.005

Mercy B, Johannes AAM. 2016. Determination of the triacylglycerol content for the identification and assessment of purity of shea butter fat, peanut oil and palm kernel oil using maldi-tof/tof mass spectroscopic technique. Int. J. Food Prop. 20, 271-280. http://dx.doi.org/10.1080/109429 12.2016.1155056

Mess A, Enthaler B, Fischer M, Rapp C, Pruns JK, Vietzke JP. 2013. A novel sampling method for identification of endogenous skin surface compounds by use of DART-MS and MALDI-MS. Talanta 103, 398-402. http://dx.doi. org/10.1016/j.talanta.2012.10.073

Mullen BF, Gabunada F, Shelton HM, Stur WW. 2003. Agronomic evaluation of leucaena. Part 2. Productivity of the genus for forage production in subtropical Australia and humid-tropical Philippines. Agroforest Syst. 58, 93-107. http://doi.org/10.1023/A:1026040631267

Mulongy K, Meersch M K V. 1998. Nitrogen contribution leucaena (leucaena leuco cephala) prunings to maiz in an alley cropping system. Bio. Fertil Soils 6, 282-285. http://doi. org/10.1007/BF00261013

Muthukrishnan P, Jeyaprabha B, Prakash P. 2013. Corrosion Inhibition of Leucaena Leucocephala pod on mild steel in sulphuric acid solution. Acta Metall. Sin. (Eng. Lett) 26, 416-424. http://doi.org/10.1007/s40195-013-0082-3

Mosmann T. 1983. Rapid colorimetric assay for cellular growth and survival: application to proliferation and cytotoxicity assays. J. Immunol. Meth. 65, 55-63. http:// dx.doi.org/10.1016/0022-1759(83)90303-4

Nehdi I A. 2013. Cupressus sempervirens var. horizentalis seed oil: Chemical composition, physicochemical characteristics, and utilizations. Ind. Crops Prod. 41, 381-385. http:// dx.doi.org/10.1016/j.indcrop.2012.04.046

Nehdi IA, Sbihi H, Tan CP, Al-Resayes SI. 2014. Leucaena leucocephala (Lam.) de Wit seed oil: Characterization and uses Ind. Crops Prod. 52, 582-587. http://dx.doi.org/10.1016/j. indcrop.2013.11.021

Schneider RCS, Baldissarelli VZ, Trombetta F, Martinelli M, Caramão EB. 2004. Optimization of gas chromatographicmass spectrometric analysis for fatty acids in hydrogenated castor oil obtained by catalytic transfer hydrogenation. Anal. Chim. Acta 505, 223-226. http://doi.org/10.1016/j. aca.2003.10.070

Pehlivana E, Arslan G, Gode F, Altun T, Özcan MM. 2008. Determination of some inorganic metals in edible vegetable oils by inductively coupled plasma atomic emission spectroscopy (ICP-AES). Grasas Aceites 59, 239-244. http://dx.doi.org/10.3989/gya.2008.v59.i3.514

Reiter B, Lorbeer E. 2001. Analysis of the wax ester fraction of olive oil and sunflower oil by gas chromatographyand gas Chromatography-mass spectrometry. $J$. Am. Oil Chem. Soc. 78, 881-888. http://doi.org/10.1007/ s11746-001-0359-z

Řezanka T, Řezanková H. 1999. Characterization of fatty acids and triacylglycerols in vegetable oils by gas chromatography and statistical analysis. Anal. Chim. Acto 398, 253-261. http://dx.doi.org/10.1016/S0003-2670(99) $00385-2$

Seenuvasan M, Selvi PK, Kumar M A, Iyyappan J, Kumar KS. 2014. Standardization of non-edible pongamia pinnata oil methyl ester conversion using hydroxyl content and GCMS analysis. J. Taiwan Inst. Chem. Eng. 45, 1485-1489. http://dx.doi.org/10.1016/j.jtice.2013.11.002

Tavassoli-Kafrani MH, Foley P, Kharraz E, Curtis JM. 2016. Quantification of nonanal and oleic acid formed during the ozonolysis of vegetable oil free fatty acids or fatty acid methyl esters. J. Am. Oil Chem. Soc. 93, 303-310. http:// doi.org/10.1007/s11746-015-2780-7

Vaclavik L, Cajka T, Hrbek V, Hajslova J. 2009. Ambient mass spectrometry employing direct analysis in real time (DART) ion source for olive oil quality and authenticity assessment. Anal. Chim. Acta 645, 56-63. http://doi. org/10.1016/j.aca.2009.04.043

Wang Y, Li C, Huang L, Liu L, Guo Y, Ma L, Liu S. 2014 Rapid identification of traditional chinese herbal medicine by direct analysis in real time (DART) mass spectrometry. Anal. Chim. Acta 845, 70-76. http://dx.doi.org/10.1016/j. aca.2014.06.014

Wang Y, Liu L, Ma L, Liu S. 2014. Identification of saccharides by using direct analysis in real time (DART) mass spectrometry. Int. J. Mass Spectrom. 357, 51-57. http://dx.doi. org/10.1016/j.ijms.2013.09.008

Xu B, Li P, Ma F, Wang X, Matthäus B, Chen R, Yang Q, Zhang W, Zhang Q. 2015. Detection of virgin coconut oil adulteration with animal fats using quantitative cholesterol by GC $\times$ GC-TOF/MS analysis. Food Chem. 178, 128-135. http://dx.doi.org/10.1016/j.foodchem.2015.01. 035 